\title{
Language Varieties Used by English Teachers in Young Learners Classes
}

\author{
Isry Laila Syathroh \\ STKIP Siliwangi Bandung \\ islaisya@yahoo.com
}

\begin{abstract}
One of the competences which teachers should possess is strategic competence. In the classes of English Language Teaching (ELT), teachers must be able to communicate either verbally or non-verbally with students to stimulate them to learn English effectively. This paper attempts to shed some light on language varieties used by English teachers in English to Young Leaners (EYL) classes. The language variation investigated is specified into the way how teachers give instruction, according to Holmes (1993), which is grouped into three categories: descriptive sentences, imperative sentences and interrogative sentences. On the ground of doing this study, two EYL teachers were involved. Since this research employs qualitative research design, the data for this study were gained through direct observation and teacher reflective notes. The study revealed that imperative sentences dominate the expressions used by teachers in EYL classes followed by questions and declarative sentences. Total Physical Response (TPR) is still assumed to be the most effective way to teach English to young learners.
\end{abstract}

Keywords: Language Varieties, English for Young Learners, English Language Teaching

\section{INTRODUCTION}

As one of international languages, English has become one of the subjects in universities, high schools, elementary schools, and even pre-schools. In the context of formal education, especially public schools, young learners in Indonesia have been introduced to English since they are in the first grade of elementary school, though English is still considered as local content (muatan local) subject.

Young learners are totally different from teenager and adult learners. Harmer (2007) elaborates eleven characteristics of young learners, which make them unique, namely:

1. They respond although they do not understand.

2. They learn from everything around them: they learn indirectly rather than directly.

3. They understand mostly when they see, hear, touch and interact rather than from explanations. Abstract concepts are difficult to deal with.

4. They generally display a curiosity about the world and an enthusiasm for learning a language.

5. They like talking about themselves and respond to learning that uses their lives as the main topic.

6. They love discovering things, making or drawing things, using their imagination, moving from one place to another, solving puzzles.
7. They have a short attention span; they can easily get bored after 5-10 minutes.

8. Teachers should have a rich repertoire of activities to help young children receive information from a variety of sources and plan a range of activities for a given time period.

9. Teachers should work with students individually or in groups.

10. Teachers need to be aware of the students' interests to motivate them.

11. The classroom should be colorful and bright with enough room for different activities.

Regarding the unique characteristics of young learners, the demand for competent English language teachers to teach young language learners is crucial. A competent English teacher must possess several teacher competencies, especially strategic competence. Teachers must be able to communicate either verbally or non-verbally with students to stimulate them to learn English effectively.

Based on the issues mentioned previously, the study is aimed at investigating the language varieties happen in young learner classes. It mainly aims to describe the variety of instruction given by teachers. To achieve the objective of the research, one research question is posed: "How do English teachers of young learners' classes give instructions?" This study is expected to provide a comprehensive description and basis for future studies related to the practice of verbal classroom interaction theoretically. From the practical view, it also hopefully gives valuable contributions to English teachers in young learner classes to reflect their teaching performance and then to plan interactive and child-friendly verbal classroom interactions.

In relation to English education program, this study professionally aims to contribute a positive impact to English teaching practices and pedagogical development according to the aforementioned background.

\section{LITERATURE REVIEW}

a. Teacher Competences and Comprehensible Input Teachers play a crucial role in education. Characteristics of competent teachers have been elaborated in Indonesian law. There are four competences which should be possessed by teachers and lecturers (Undang-Undang No.14 Tahun 2005): pedagogical competence, personality competence, social competence and professional competence. Pedagogical competence refers to the ability to understand students, to plan and implement teaching and learning 
process, to evaluate learning outcomes and develop students with their potentials. Personality competence refers to the ability to reflect stable and wise individual and to become a good model for his or her students. Professional competence refers to the ability to master learning materials, including the curriculum and the methodology. Finally, social competence refers to the ability to communicate and interact effectively with students, fellow teachers, students' parents and nearby society.

In the context of teaching and learning process, several studies about teacher and students interactions have been conducted by scholars. For example, Coulthard (1977) who found that pedagogical discourse is different from natural discourse. Coulthard claims that teachers usually modify their speech during instruction in a way that resembles caregiver talk but with some peculiar and distinct features at the level of phonology, lexis, syntax, and discourse. In other words, teacher speech is usually modified variously based on the task and the students' level of proficiency. Scarcella and Oxford (1992) and Chaudron (1988) cited in Debat (2002) add that the characteristics of teachers' modified speech are higher pitch, exaggerated intonation, short sentences, recurrent use of intonation, lower rate of speech, more frequent pauses, exaggerated pronunciation, basic vocabulary, low degree of subordination, use of declarativess and statements, and repetition. Osborne (1999) summarizes that teacher speech with young learners is usually made simple, shorter and more careful pronounced to make it clearer and more comprehensible.

Previous studies have also been conducted to investigate the importance of comprehensible input. Krashen (1985) claims that students should get large amounts of comprehensible input for acquisition. The optimal comprehensible input for learners is a little below students' level of proficiency (i+1). Moreover, input for students can be made comprehensible using verbal and non-verbal clues. Other studies also done by Hatch (1983) and Enright (1991) which revealed some characteristics of comprehensible input at the different linguistic level, for example: pronunciation (fewer reduced vowels and contractions, slow rate and longer pauses), vocabulary (less slang and fewer idioms, fewer pronoun forms, use of gestures and pictures), grammar (shorter utterances, repetitions and restatements, more collaborative completion), discourse (requests for clarification, more frames, such as ok, salient conversation components), non-verbal adaptation (gestures, mimes, etc), contextual (visual and auditory aids), para-verbal (speaking clearly, slowing pace, using pauses) and discourse (rephrasing, repetition).

\section{b. Types of Teacher Instruction}

There are many ways to give instructions. Holmes (1983) as cited in Debat (2002) elaborates three different ways of giving instructions (directives):
Table 1. Teachers' Directives

\begin{tabular}{lll}
\hline Teachers' Directives & \\
\hline Types & Form & Example \\
\hline Imperatives & Verb 1 & Speak louder \\
& You & You go on with the \\
& imperatives & work \\
& Present & Looking at me \\
& Participle & Hands up \\
& Verb Ellipsis & Turn around, please \\
& Imperatives & Joe \\
& modifier & Let's try \\
& Let's Verb 1 & \\
\hline Declaratives & Modals & Will you read this \\
& Non-modals & page for me? \\
& & $\begin{array}{l}\text { People at the back } \\
\text { are you listening? }\end{array}$ \\
& & I want you to draw \\
& Embedded & a picture \\
Interrogatives & Sally, you are not \\
(Questions) & Hints & saying much \\
\hline Holmes' & Syntactic Forms of & Directives (Cited in
\end{tabular}

Holmes' Syntactic Forms of Directives (Cited in Debat, 2002)

From the literature review and previous studies above, it can be concluded that teachers of English to young learners need to develop an awareness of the importance of effective communication with them, especially in giving instruction. Teachers should also be aware of young learners' characteristics so successful teaching and learning process can be achieved.

\section{RESEARCH METHODOLOGY}

In line with the purpose, this study adopted a descriptive qualitative study. Qualitative research methods are used to examine questions that can best be answered by verbally describing how participants in a study perceive and interpret various aspect of their environment (Crowl: 1996). The qualitative data is collected from an appropriate data source in order to answer the research question. The researcher serves as the main instrument of the research. According to Miles and Huberman (1992), qualitative research design employs naturalistic enquiry which places the researcher as the instrument. The data were collected through direct observation by using audio-recorder. Direct observation was used to see the teaching and learning process in two young learner classes in one private English course in Bandung. Each class was recorded for about 60 minutes. Two English teachers participated in this research. The first participant is a local English teacher with 10 year-experiences in teaching English. The teacher has not taken CELTA training yet. The second participant is a native teacher (Australian) with 8 year-experiences in teaching English. The teacher also has taken CELTA training. The selection of the participants was based on convenient sampling. It is a non-probability sampling technique where subjects are selected because of 
their convenient accessibility and proximity to the researcher (Crowl, 1996).

\section{FINDINGS AND DISCUSSION}

This study identifies some findings. First, from the two observed young learner English classes, it was found imperative sentences dominate the expressions used by teachers in EYL classes followed by questions and declarative sentences. In giving instructions, the two teachers use direct imperative sentences. The calculation of teacher speech can be seen from the table below:

Table 2. The calculation of teacher speech

\begin{tabular}{|c|c|c|c|c|c|c|c|c|c|c|c|}
\hline \multicolumn{6}{|c|}{ Teacher 1} & \multicolumn{6}{|c|}{ Teacher 2} \\
\hline $\mathbf{I}$ & $\%$ & D & $\%$ & $\mathbf{Q}$ & $\%$ & I & $\%$ & D & $\%$ & $\mathbf{Q}$ & $\%$ \\
\hline 2 & 67 & 7 & 21 & 4 & 14 & 2 & 73 & 5 & 12 & 6 & 15 \\
\hline 3 & $\%$ & & $\%$ & & $\%$ & 9 & $\%$ & & $\%$ & & $\%$ \\
\hline
\end{tabular}
below:

For more clear illustration of each teacher, see the figure

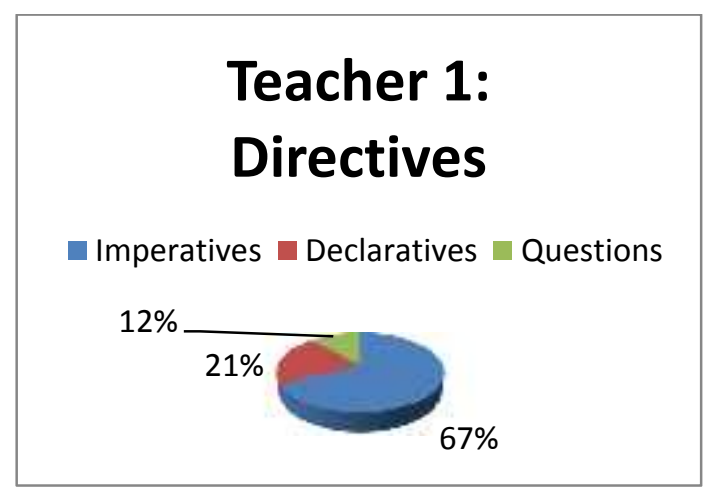

Figure 1: Types of Directives

Figure 1 above shows that teacher 1 gives instruction in various ways: direct instruction (23 utterances), declarative (7 sentences) and questions (4 utterances). From the total of 34 utterances, imperative sentences dominate the whole utterances of instruction, for about $67 \%$. The result implies that the teacher is aware of the characteristic of young learners that they will find it difficult to understand abstract concept, that is why the teacher used imperative sentences in giving instruction to make it clear and understandable.

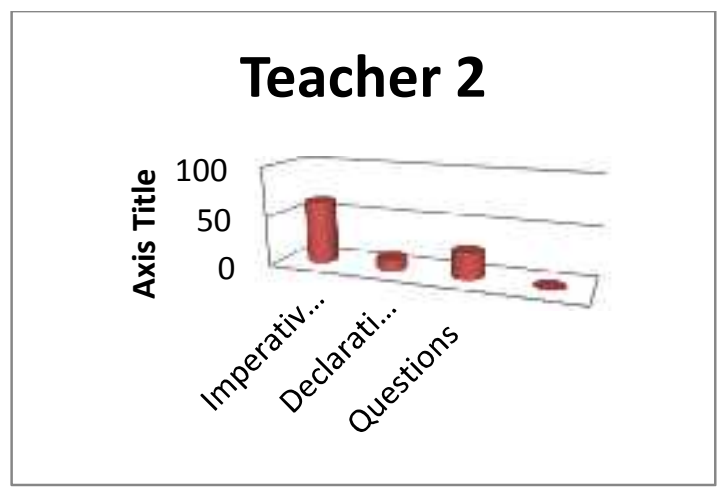

Figure 2: Types of Directives

Figure 2 above shows that teacher 2 also gives instruction in various ways: direct instruction (29 utterances), declarative (5 sentences) and questions (6 utterances). From the total of 40 utterances, imperative sentences also dominate the whole utterances of instruction, which is about $73 \%$. The result also implies that the teacher is trying to make the instruction clear and understandable by imperative sentences.

\section{CONCLUSION}

From the finding of this study, it can be concluded that teachers of English in young learner classes had shown language varieties, especially in giving instruction. From the two participants of this research, in giving instruction, teachers used more imperatives rather than declaratives and questions. This study in line with what Ur (1991) and Wright (2003) who elaborates the effective characteristics of effective teacher commands. The instruction must be brief, referring to one task at a time, and aided with gestures and aids to demonstrate meanings.

\section{REFERENCES}

Chaudron, C. (1988). Second language classrooms: Research on teaching and learning. USA: Cambridge University Press.

Coulthard, M. (1977). An introduction to discourse analysis. London: Longman

Crowl, T.K. (1996). Fundamentals of education research. United States: Brown and Benchmark Publisher.

Debat, Susana Maria. 2002. Giving oral instruction to EFL young learners. Encuentro Revista de investigación e innovación en la clase de idiomas. \{Retrieved in August 21, 2016\}

Enright, S. (1991). Supporting children's English language development in grade level language classrooms. In Celce-Murcia (ed.) Teaching English as a Second or Foreign Language. USA: Heinle \& Heinl

Harmer, J. (2007). How to teach English. Essex: Pearson Educational Limited.

Hatch, E.M. (1983). Psycholinguistics: A Second Language Perspective. Newbury House Publishers, Inc., Rowley, MA 01969. 
Holmes, J. (1983). The structure of teachers'directives. In Richards, J. and Schmidt, R. (eds.) Language and Communication. England: Longman.

Krashen, S. D. (1985). The input hypothesis: Issues and implications. New York: Longman

Miles, M. B. \& Huberman, A. M. (1992). Qualitative data analysis. Thousand Oaks California: Sage Publication.

Nunan, D. (1995). Language teaching Methodology: A textbook for Teacher. Great Britain: Prentice Hall Europe.
Osborne, D. (1999). “Teacher's talk". In A Sociolinguistic Variable \ Forum (Vol. 3, No. 2, pp. 10-16).

Ur, P. (1991). Course in language teaching: Practice and theory. Cambridge: Cambridge University Press.

Undang-Undang No.14 Tahun 2005

Wright, J. (2003). Effective teacher commands: establishing classroom control. In The Sawy Teacher's Cuide: Selected Ideas for Behavioral Intervention. www. Interventioncentral.org. 